\title{
INVESTIGATION OF THE MECHANICAL AND TECHNOLOGICAL PROPERTIES OF FODDER CROPS TO DETERMINE THE PARAMETERS OF THE WORKING BODIES OF MOWER CONDITIONERS AND OPTIMAL MODES OF THEIR OPERATION
}

\author{
Vitalii Komaha, $\mathrm{PhD}$, Senior Lecturer \\ Oleksii Tokarchuk, PhD, Associate Professor \\ Mykhailo Zamrii, student \\ Vinnytsia National Agrarian University
}

\author{
Комаха Віталій Петрович, к.т.н., старший викладач \\ Токарчук Олексій Анатолійович, к.т.н., доцент \\ Замрій Михайло Анатолійович, студент \\ Вінницький національний аграрний університет
}

\begin{abstract}
In modern conditions, with insufficient resource supply for agriculture, the most popular in fodder production is resource-saving technologies that increase production of highly nutritious feed at a low cost of labor and money. In field fodder production, resource conservation can be achieved through the wider use of new approaches and crops in the harvesting - perennial leguminous grasses for harvesting hay, which have high environmental sustainability and competitive ability. The most important task of intensifying livestock in the winter is the harvesting of hay (haylage) from crops with a high content of protein and protein (carotene). As a result of the study of the size-mass characteristics of the most valuable feed-rich crop, rich in protein and amino acids, which is important when developing methods for preparing fodder from perennial leguminous herbs - alfalfa. Knowing the properties of alfalfa will allow to really reach the design and technological parameters. The linear dimensions of alfalfa are given to enable the design of mower conditioners with vertical placement of conditioner rollers (sizes of working bodies, their setting and operating modes).

According to the long-term results of the study of the size-mass characteristics of alfalfa, the features of varying the marked features and their correlation are established. Research data after mathematical processing made it possible to identify the correlation between the length of the stalk of alfalfa and its stability, which is an important indicator in the design of working bodies and the establishment of appropriate operating modes of mower conditioners with a vertical conditioner.
\end{abstract}

Key words: alfalfa, size and mass characteristics, feed production, profitability, harvesting technology, mower conditioner.

F. 2. Fig. 7. Table. 4. Ref. 20.

\section{Introduction}

At the present stage of development of the economy of Ukraine, it is important to increase the efficiency of use and reduce the energy intensity of existing technological equipment by its modernization. But at the same time, in the development of methods and means for mowing with the simultaneous treatment of grasses in domestic spaces stagnation the following is observed - traditional approaches have almost exhausted their capabilities, and new ideas are still far from widespread adoption in production. The development of machines to implement methods that would enable the production high quality hay is of particular importance in these conditions.

\section{Analysis of recent research and publications}

Among the fodder herbs, alfalfa is a cheap and rich source of high-grade protein in amino acid composition $[1,2,3]$. No wonder the ancient Arabic name of alfalfa al-alpha, which means the first, the best $[4,5]$.

The alfalfa leaves contain xanthophylls, vitamins, trace elements, non-nitrogenous extractives (glucose, fructose, sucrose, starch - about $10-12 \%$ ) $[6,7,8,9]$. Of the 50 different species (36 species in the CIS), alfalfa has four production values: alfalfa blue sowing, alfalfa yellow sickle, blue and hybrid (medium) 


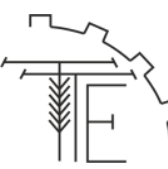

[10]. The sown area of alfalfa in the CIS reaches 8 - 9 million hectares, of which 1800,000 hectares in Ukraine, $48 \%$ in the structure of perennial grasses.

The best is considered to be hay with well-leafed alfalfa, which allows to balance carbohydrate feeds in protein content. However, for a number of advantages inherent in this culture, it should be noted that in the drying process there is an uneven moisture content of its components. Leaves give moisture more intensively than stems $[11,12,13]$.

To eliminate this drawback, according to Pavlov D.V. "One of the effective technical means that can significantly accelerate the shedding of grasses and thereby improve the quality of hay is mowerconditioners" [14]. To date, foreign manufacturers (in Ukraine there is no production of mower-conditioners) use the horizontal arrangement of rollers, but with such a complete set, the acceleration of grass drying is only 10-13\% [15, P.97] compared with the usual method without rolling, and the use of vertical flattening rollers will allow to increase the degree of drying by $41-61 \%$ [16, P.46].

There are technical solutions in the implementation of the mower-conditioner with the vertical placement of the rollers $[17,18]$. When applied, the treatment is subjected to the entire stem in length (to reduce the impact of the roll), or the root part (to preserve the leaves).

According to research by Kondratyuk D. and Komakha V. it is necessary to treat only the upper half of the stem length, which will accelerate the branching [19]. The strength of the radial part of the alfalfa stalk, in the period of harvesting it for hay, is greater than the strength of the stalk of the upper part 1.5 times [20]. However, none of the known designs of mowers-conditioners so far does not allow the cultivation of the upper half of the plants.

\section{Formulation of the problem}

For the purpose of the scientific approach during the design of the mower-conditioner, which would allow processing of the upper half of the plant, it is necessary to study the size-mass characteristics of the crops, in our case alfalfa, as the most valuable forage, namely - linear dimensions. Knowledge of these properties will allow to really reach the structural and technological parameters.

\section{Key research results}

Natural alfalfa stalks of blue sowing in the amount of 102 samples were used for the studies, which were taken during full budding - the beginning of flowering. Due to the loss of humidity alfalfa was harvested just before the experiment.

The length of the stem was determined using a metric ruler with an error of $1 \mathrm{~mm}$, as shown in Fig. 1 , and the diameter using a caliper with an accuracy of $0.05 \mathrm{~mm}$. Stem diameter measurements were performed in 3 places along the length: directly at the point of the cut, in the middle part and at the apex - at the place of the last branching.

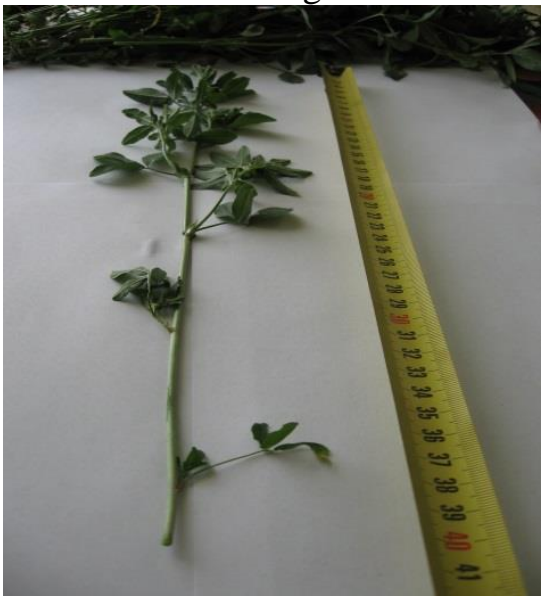

a)

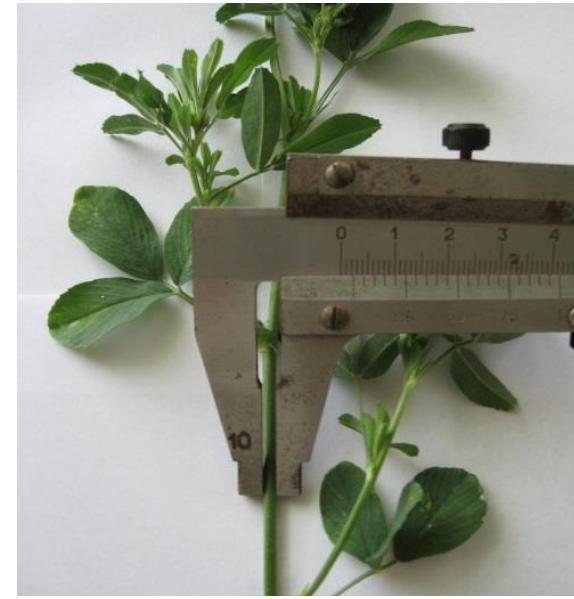

b)

Fig. 1. Investigation of the dimensional characteristics of alfalfa: a) length measurement; b) stem diameter measurements

To determine the center of gravity, the plant was first weighed to the nearest $0.01 \mathrm{~g}$, after which the plant was enclosed with a middle part on a conical part of the pyramid. Moving the plant in one direction or 


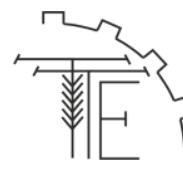

another achieved its balanced position. The distance from the point of equilibrium to the cut-off section is the height of the center of gravity of the plant (see Fig. 2).

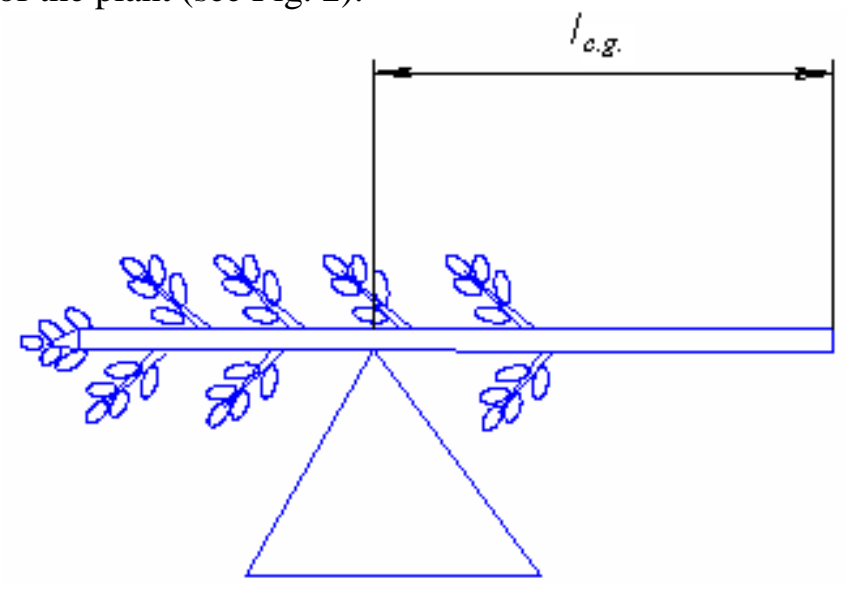

Fig. 2. Scheme of determining the center of gravity of the plant

Flattening of the upper half requires that the flattening section be placed at a certain height relative to the surface of the field. Generalized statistical indicators of the measurements of length over three years are summarized in Table 1.

Table 1.

Summarizing the length of alfalfa in the context of 3 years

\begin{tabular}{|l|c|c|c|}
\hline Value: & $\begin{array}{c}\text { Generalizing values of } \\
\text { alfalfa length in 2017, } \\
\text { centimeters }\end{array}$ & $\begin{array}{c}\text { Generalizing values of } \\
\text { alfalfa length in 2018, } \\
\text { centimeters }\end{array}$ & $\begin{array}{c}\text { Generalizing values of alfal } \\
\text { length in 2019, centimeter }\end{array}$ \\
\hline minimum & 47,9 & 35,0 & 40,6 \\
\hline middle & 64,8 & 49,4 & 60,6 \\
\hline maximum & 81,8 & 63,8 & 80,5 \\
\hline
\end{tabular}

After processing the obtained data, a histogram of the distribution of alfalfa plants was constructed, which makes it possible to determine the height of the flattening section relative to the field surface (see Fig. $3)$. As we can see, the length of alfalfa for three years varies significantly: fluctuates over a considerable period of three years:

- $\quad$ in 2018 it was within $50 \mathrm{~cm}$;

- in 2017 and 2019 it was about $70 \mathrm{~cm}$.

This difference was due to the climatic conditions in the spring.

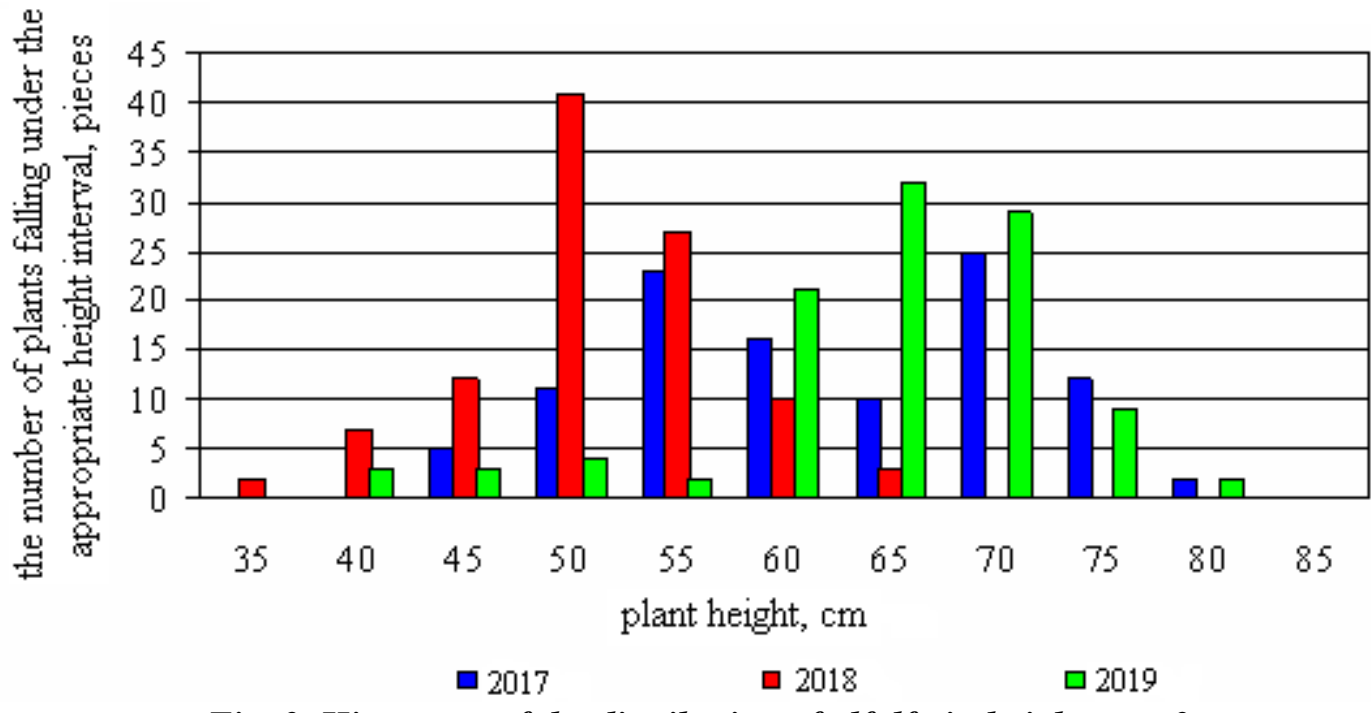

Fig. 3. Histogram of the distribution of alfalfa in height over 3 years 


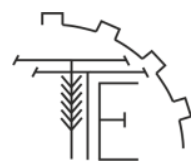

Vol. 108, No 1 / 2020

Climatic conditions significantly affect the length of alfalfa, as evidenced by its fluctuations in a significant range from 35 to $82 \mathrm{~cm}$.

When measuring the length, it was noted that alfalfa stems have different diameters. The average value of three measurements determined the diameter of the stem. The obtained stem diameter values allowed us to divide them into three groups (thin, medium, rough). To identify the most dominant group, the obtained data were processed and presented in Table 2. Based on this, the distribution of the diameters of alfalfa stem diameters within three years was constructed (see Fig. 4).

Table 2

Quantitative indicators of groups of diameters of alfalfa stems

\begin{tabular}{|l|c|c|c|c|}
\hline \multirow{2}{*}{$\begin{array}{c}\text { Groups of diameters of alfalfa } \\
\text { stems }\end{array}$} & \multirow{2}{*}{ Limits } & \multicolumn{3}{c|}{$\begin{array}{c}\text { The number of stems that fall within the } \\
\text { appropriate limits }\end{array}$} \\
\cline { 3 - 5 } & & 2017 & 2018 & 2019 \\
\hline Thin & $0,6-1,4$ & 28 & 36 & 13 \\
\hline Medium & $1,5-2,3$ & 67 & 54 & 51 \\
\hline Rough & $2,4-3,6$ & 7 & 12 & 38 \\
\hline
\end{tabular}

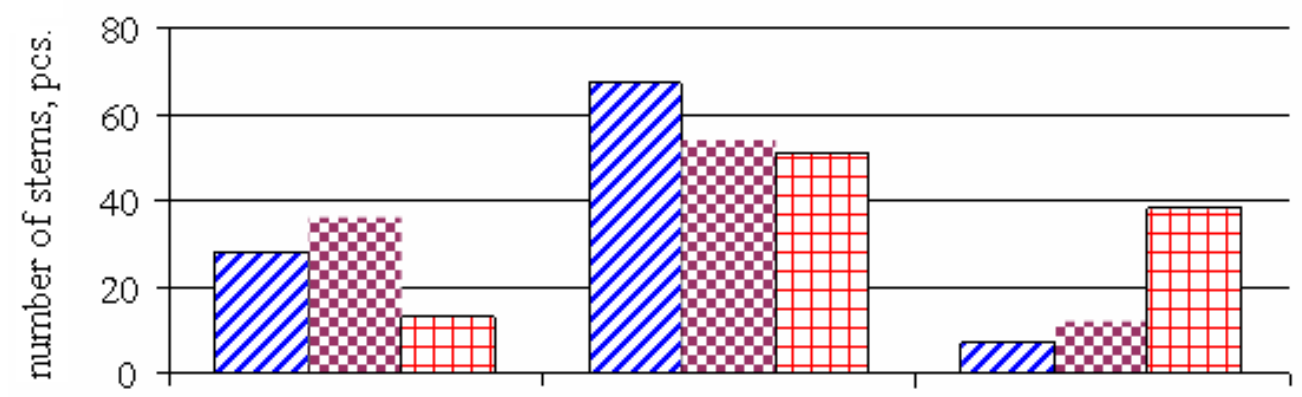

0.6 thin stems $1.4 \quad 1.5$ medium stems 2.32 .4 rough stems 3.6
Z 2017
$\$ 2018$
$\boxplus 2019$

Fig. 4. Distribution of diameter limits of alfalfa stems

An analysis of the distribution of the boundaries of the diameters of the stems over three years allows us to conclude that the most prevalent in 3 years were the stems with an average diameter of $1.5 \mathrm{~mm}$ to $2.3 \mathrm{~mm}$.

Table 3

The influence of the length of alfalfa on the diameter of its stem

\begin{tabular}{|c|c|c|c|c|}
\hline \multirow{2}{*}{ Years } & \multirow{2}{*}{ Length interval } & \multicolumn{3}{|c|}{ Number of stems: } \\
\hline & & thin & medium & rough \\
\hline \multirow{4}{*}{2017} & $45-55$ & 12 & 4 & - \\
\hline & $55-65$ & 14 & 21 & - \\
\hline & $65-75$ & 2 & 21 & 3 \\
\hline & $75-85$ & - & 21 & 4 \\
\hline \multirow{5}{*}{2018} & $35-45$ & 2 & 20 & 1 \\
\hline & $45-55$ & 34 & 22 & 1 \\
\hline & $55-65$ & - & 12 & 10 \\
\hline & $65-75$ & - & - & - \\
\hline & $75-85$ & - & - & - \\
\hline \multirow{5}{*}{2019} & $35-45$ & 3 & - & - \\
\hline & $45-55$ & 6 & 2 & 0 \\
\hline & $55-65$ & 4 & 20 & 3 \\
\hline & $65-75$ & - & 25 & 29 \\
\hline & $75-85$ & - & 4 & 6 \\
\hline
\end{tabular}




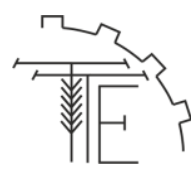

Having examined the length of alfalfa and the diameter, we determine whether there is a relationship between them. Having received the minimum and maximum values of the length of alfalfa (for example, for 2017 they are within the limits of $45 \ldots 85 \mathrm{~cm}$ ), divided into intervals that are multiples of 10 (see Table 3), and calculated the number of stems of the corresponding groups belonging to the created limits. The obtained values are expressed graphically in the form of a histogram, to determine whether the diameter depends on length.

Analyzing the histogram (Fig. 5), with a length of alfalfa from $45 \mathrm{~cm}$ to $65 \mathrm{~cm}$, a significant amount of thin stems is observed. Moreover, their number decreases toward increasing the length. Alfalfa with medium diameter stems are present almost within all length intervals. However, with an increase in height, there is a tendency of their decrease, with the exception of 2017. Rough stems in alfalfa are already found at a length of $65 \mathrm{~cm}$, but their number at this length is relatively small, which also increases with the increase in length, with the exception of 2019. Therefore, from the above analysis of the correlation of length and diameter, we can conclude that the higher the alfalfa, the rougher it stems.

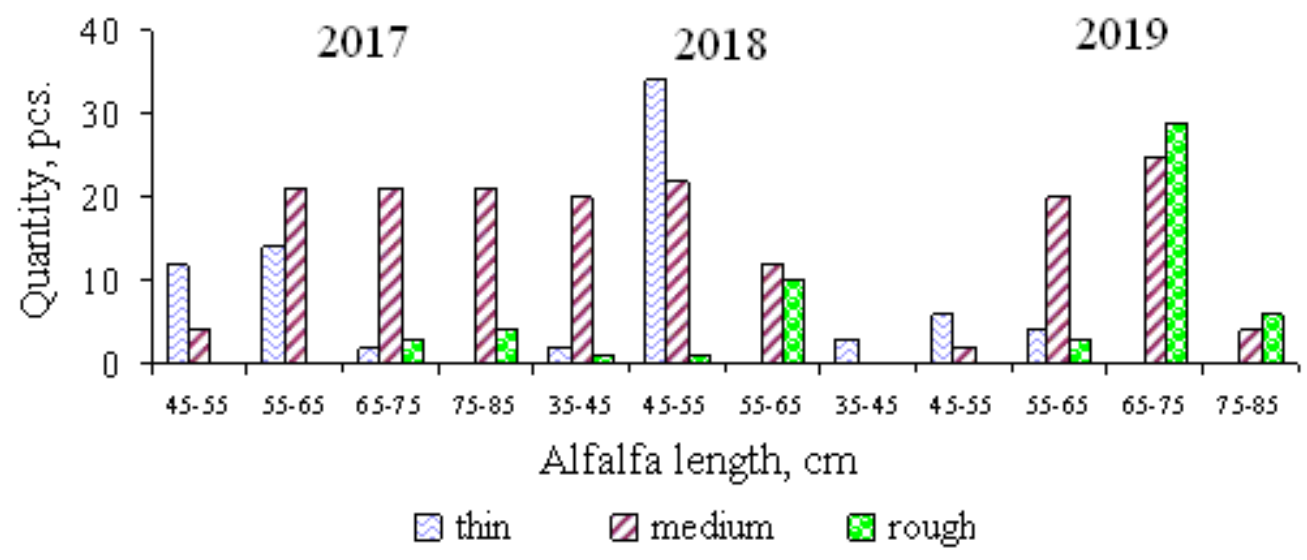

Fig. 5. Investigation of the effect of length on diameter for 3 years

Since the beveled alfalfa is transported to the rolling zone, it is therefore necessary to determine the center of gravity and its relation to the length. The center of gravity $\mathbf{L}_{\mathbf{c} . g}$. is the distance from the equilibrium point of the plant to the cut-off section. The center of gravity $\mathbf{L}_{\text {c.g. }}$ is located at a distance of $23.6 \ldots 49 \mathrm{~cm}$ from the basal part and crosses half the total length of alfalfa, which was $40.6 \ldots 80.5$ when determining the center of gravity (see Table 4).

The general indicators of the measurements made in 2019 are summarized in Table. 4.

Generalized indicators of alfalfa production in 2019 to determine sustainability

Table 4

\begin{tabular}{|c|c|c|c|c|c|c|c|c|c|c|c|c|}
\hline \multirow{2}{*}{ Indicators } & \multicolumn{3}{|c|}{ Length, $\mathrm{cm}$} & \multicolumn{3}{|c|}{$\begin{array}{l}\text { The diameter of the } \\
\text { root part of the stem, } \\
\mathrm{mm}\end{array}$} & \multicolumn{3}{|c|}{ Weight, gr } & \multicolumn{3}{|c|}{ Weight center, $\mathrm{cm}$} \\
\hline & $\min$ & $\max$ & medium & $\min$ & $\max$ & medium & $\min$ & $\max$ & medium & $\min$ & $\max$ & medium. \\
\hline Value & 40,6 & 80,5 & $60,6,1$ & 0,6 & 3,2 & 2,1 & 1,04 & 6,3 & 3,1 & 23,6 & 49,0 & 39,2 \\
\hline
\end{tabular}

It was established that between the center of gravity $\mathbf{L}_{\mathbf{c} . g .}, \mathrm{cm}$ and length $\mathbf{L}_{\mathbf{p} .}, \mathrm{cm}$ for alfalfa with a correlation coefficient $r=0.6908$, there is a dependence of the form:

$$
\mathbf{L}_{\text {c.g. }}=0.5763 \mathbf{L}_{\text {p. }}+1.0236 \text {. }
$$

Dependence (1) was established according to the research data and is shown in Fig. 6, which shows that the center of gravity increases linearly with increasing length.

The position of alfalfa in space is characterized by such a parameter as the stability of the stem. The stability of the alfalfa stem $\mathbf{G}$ is the ratio of the height of the center of its weight $\mathbf{L}_{\text {c.g. }}$ to the diameter of the base $\mathbf{D}_{\text {base. }}$

Research data after mathematical processing made it possible to identify the relationship between the length Lp. and plant resistance G (see Fig. 7). Here, the most likely turned out to be a power dependence with a fairly high correlation coefficient of 0.9194 :

$$
\mathbf{G}=22.0735 \mathbf{L}_{\text {p. }} 1.6801 \text {. }
$$




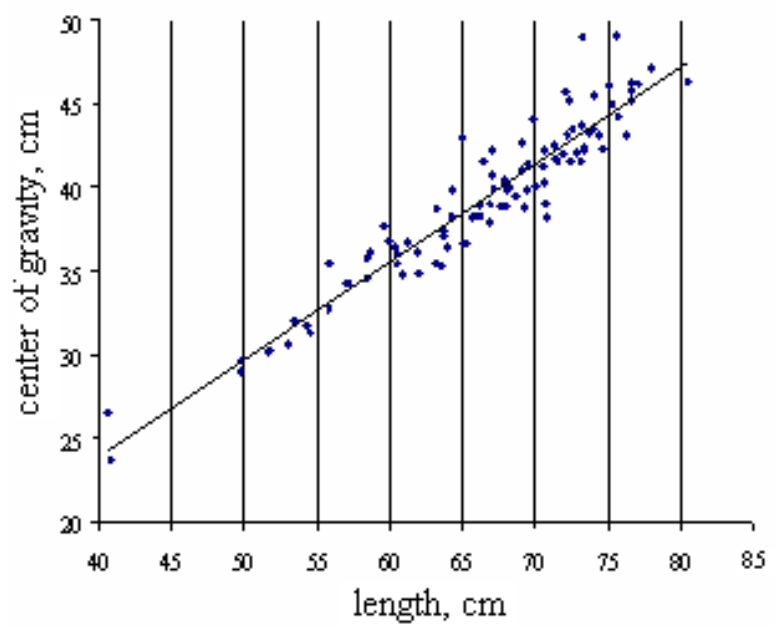

Fig. 6. Dependence of the center of gravity on the length of alfalfa

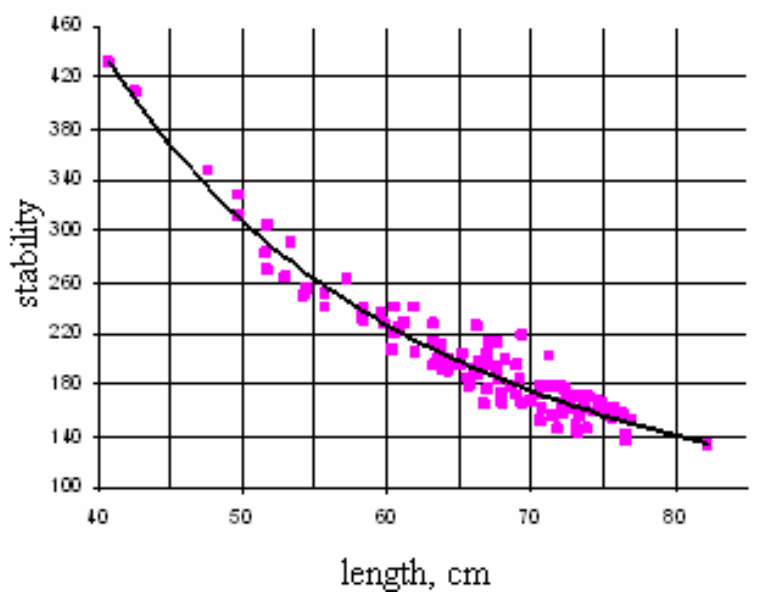

Fig. 7. Effect of alfalfa length on its stability

\section{Conclusion}

According to the analysis of literary sources, alfalfa was taken to be the object of study as a highly profitable forage crop.

The study of the size-mass characteristics of alfalfa, carried out for three years, allows us to clearly determine the range of changes in linear dimensions and identify their correlation.

The data obtained during the research can be used in the design of mower conditioners with vertical placement of rollers.

Since climatic conditions significantly affect the linear dimensions, it becomes necessary to use a hydraulic circuit to control the flattening section relative to the field surface, depending on the length of the plants.

\section{References}

[1] Filatov, I. I., Mityakov, V. P., Mityakova, R. P. (1976). Sposobyi konservirovaniya i ispolzovaniya kormov iz lyutsernyi i kostra bezostogo [Methods of preserving and using feed from alfalfa and campfire]. Zhivotnovodstvo, 5, 50-52 [in Russian].

[2] Iopa, I. L., Sereda, P. Ya., Shvetsov, H. H. (1983). Sravnitelnaya otsenka kormov iz lyutsernyi [Comparative evaluation of alfalfa feed]. Kormoproizvodstvo, 7, 25-26. [in Russian].

[3] Vavilov, P. P., Pasyipanov, G. S. (1983). Bobovyie kulturyi i problemyi rastitelnogo belka [Legumes and vegetable protein problems]. M.: Rosselhozizdat. [in Russian].

[4] Vasilchenko, I. T. (1949). Lyutserna, luchshee kormovoe rastenie [Alfalfa, the best fodder plants]. Trudyi Botan. instituta AN SSSR, 8, 95-119. [in Russian].

[5] Dan Undersander (2007). Alfalfa Best Practices University of Wisconsin. [in English].

[6] Gubaydullin, H. G., Enikeev, R. S. (1982). Lyutserna na korm i semena [Alfalfa for feed and seeds]. M.: Rosselhozizdat. [in Russian].

[7] Lupashku, M. F. (1977). Lyutserna na kormovyie tseli [Alfalfa for forage purposes]. KishinYov: Kartya Moldovinyaske. [in Russian].

[8] Lubenets, P. A. (1977). Kormovoe dostoinstvo i himicheskiy sostav lyutsernyi [Alfalfa feed value and chemical composition]. Trudyi po prikladnoy botanike, genetike i selektsii, 1(59). 88-117. [in Russian].

[9] Martovitskaya, A. M., Buryikina, S. I., Martovitskiy, P. I. (1984). Kachestvo proteina v kormah iz lyutsernyi [Alfalfa Protein Quality]. Kormoproizvodstvo, 10, 16-18. [in Russian].

[10] Zinchenko, B. S. (1975). Bagatorichni bobovi travy [Perennial legumes]. K. : Urozhaj. [in Ukrainian].

[11] Milyutina, K. F. (1984). Poteri v protsesse uborki i hraneniya lyutsernyi i krasnogo klevera [Losses during harvesting and storage of alfalfa and red clover]. Selskoe hozyaystvo za rubezhom, 6, 36-38. [in Russian]. 


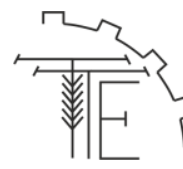

[12] Malyk, O. G. (1995). Problemy vykorystannya vysokobilkovyx kormiv u godivli tvaryn [Problems of using high-protein feed in animal feeding]. Mizhvid. temat. nauk. zbirn. "Problemy" agropromyslovogo kompleksu Karpat». V. Bakta: Karpaty, 4. 207-214. [in Ukrainian].

[13] Kondratyuk, D. G. (1994). Vplyv deyakyx faktoriv na nerivnomirnist' sushinnya konyushyny luchnoyi [The influence of some factors on the uneven drying of clover]. Persha vseukrayinska (Mizhnarodna) konferenciya po problemi «Kormy i kormovyj blok». Pid red. akademika UAAN, chlena koryspodenta RASGN prof. A.O. Babycha. Vinnycya. [in Ukrainian].

[14] Gubarev, A. N., Pavlov, D. V. (1989). Rezultatyi laboratorno - polevyih ispyitaniy navesnoy rotatsionnoy kosilki s bilnyimi konditsionerami razlichnyih konstruktsiy [Results of laboratory field tests of a mounted rotary mower with flexible air conditioners of various designs]. Trudyi VNII KOMZh. Problemyi sozdaniya mashin i oborudovaniya dlya zhivotnovodstva. 38-47. [in Russian].

[15] Klinner, M. E., Hale, O. D. (1984). Desing waluation of crop conditioners with plastic. «J. Agr. Eng. Res.», 3. 30. [in English].

[16] Haydu, Y. (1984). Preimuschestva kosilok-plyuschilok pri zagotovke sena [Advantages of mower conditioners for hay]. Mehanizatsiya i elektrifikatsiya selskogo hozyaystva, 1. 94-98. [in Russian].

[17] Sposob podgotovki kormovyih rasteniy $k$ sushke [A method for preparing feed plants for drying] : A. s. 3544510/30-15 SSSR/ Yu. A. Evdokimov, V. R. Toropov (SCSR). №1153856; Zayavleno 21.01.83; Opubl. 07.05.85, Byul. №17. 2p.

[18] Kosilka-plyuschilka [Mower conditioners]: A.s. 1650732/30-15 SSSR/ V. V. Lavrenov, P. S. Orlov, A. A. Skitskiy (SSSR). №375050; Zayavleno 19.04.71; Opubl. 23.03.73, Byul. №16. 2p.

[19] Derevyanko, D. A., Kondratyuk, D. G., Komaxa, V. P. (2008). Intensyfikaciya procesu provyalyuvannya riznyx chastyn stebla bobovyx trav pry dopomozi plyushhennya [Intensification of the process of cutting through different parts of the legume stem by flattening]. Zbirnyk naukovyx pracz Kirovogradskogo nacionalnogo texnichnogo universytetu, Kirovograd: Kirovogradskyj nacionalnyj agrarnyj universytet, 21. 160-163. [in Ukrainian].

[20] Komaxa, V. P. (2009). Vyznachennya micznosti riznyx chastyn stebla bobovyx trav [Determination of strength of different parts of the legume stem]. Zbirnyk naukovyx pracz Vinnyczkogo derzhavnogo agrarnogo universytetu, Vinny`cya: Vinnyczkyj derzhavnyj agrarnyj universytet. Vypusk 2. [in Ukrainian].

\section{ДОСЛІДЖЕННЯ МЕХАНІКО-ТЕХНОЛОГІЧНИХ ВЛАСТИВОСТЕЙ КОРМОВИХ КУЛЬТУР ДЛЯ ВИЗНАЧЕННЯ ПАРАМЕТРІВ РОБОЧИХ ОРГАНІВ КОСАРОК-ПЛЮЩИЛОК І ОПТИМАЛЬНИХ РЕЖИМІВ ЇХ РОБОТИ}

В сучасних умовах при недостатньому ресурсному забезпеченні сільського господарства найбільш затребуваними в кормовиробництві є ресурсозберігаючі технології, що забезпечують збільшення виробництва високопоживних кормів при невеликих затратах пращі $i$ коштів. $У$ польовому кормовиробництві ресурсозбереження можна досягти за рахунок більш широкого використання в заготівлі нових підходів і культур - багаторічних бобових трав для заготівлі сіна, що володіють високою екологічною стійкістю і конкурентною здатністю.

Найважливішим завданням інтенсифікаиії тваринництвва в зимовий період є заготівля сіна (сінажу) з культур з високим вмістом білка та протеїну (каротину). В результаті проведено дослідження розмірно-масових характеристик найбільш иінної в кормовому відноменні культури, багатої на білок та амінокислоти, що є важливим при розробиі прийомів заготівлі кормів з бобових багаторічних трав, - лючерни. Знання властивостей люиерни дозволить реально вийти на конструктивні та технологічні параметри. Наведені лінійні розміри люцерни надають можливість проектування косарок-плющилок з вертикальним розміщенням плющильних вальців (розміри робочих органів, їх налагодження та режими роботи).

За багаторічними результатами дослідження розмірно-масових характеристик люиерни встановлено особливості варіювання відмічених ознак $i$ їх взаємозв'язок. Дані досліджень після математичного обробітку забезпечили можливість виявлення зв'язку довжини стебла люиерни до ї стійкості, що є важливим показником при проектуванні робочих органів та встановлення відповідних режимів роботи косарок-плющилок з вертикальним плющильним апаратом.

Ключові слова: лючерна, розмірно-масові характеристики, кормовиробництво, рентабельність, технологія заготівлі, косарка-плющилка.

Ф. 2. Рис. 7. Табл. 4. Літ.20 


\section{ИССЛЕДОВАНИЕ МЕХАНИКО-ТЕХНОЛОГИЧЕСКИХ СВОЙСТВ КОРМОВЫХ КУЛЬТУР ДЛЯ ОПРЕДЕЛЕНИЯ ПАРАМЕТРОВ РАБОЧИХ ОРГАНОВ КОСИЛОК- ПЛЮЩИЛОК И ОПТИМАЛЬНЫХ РЕЖИМОВ ИХ РАБОТЫ}

В современных условиях при недостаточном ресурсном обеспечении сельского хозяйства наиболее востребованныли в кормопроизводстве является ресурсосберегающие технологии, обеспечиваюшие увеличение производства высокопитательных кормов при небольших затратах труда и средств. В полевом кормопроизводстве ресурсосбережения можно достичь за счет более широкого использования в заготовке новых подходов и культур - многолетних бобовых трав для заготовки сена, обладаюших высокой экологической устойчивостью и конкурентной способностью.

Важнейшей задачей интенсификачии животноводства в зимний период является заготовка сена (сенажа) из культур с высоким содержанием белка и протеина (каротина). В результате проведения исследования размерно-массовых характеристик наиболее иенной в кормовом отношении культуры, богатой белком и аминокислоты, что является важным при разработке приемов заготовки кормов из бобовых многолетних трав - лючерны. Знание свойств люиерны позволит реально выйти на конструктивные и технологические параметры. Приведены линейные размеры люиерны предоставляют возможность проектирования косилок-плющилок с вертикальным размещением плющильных вальцов (размеры рабочих органов, их настройка и режимы работы).

По многолетним результатам исследования размерно-массовых характеристик люиерны установлены особенности варьирования отмеченных признаков и их взаимосвязь. Данные исследований после математического обработки обеспечили возможность выявления связи длины стебля лючерны к ее устойчивости, что является важным показателем при проектировании рабочих органов и установления соответствующих режимов работы косилок-плющилок $c$ вертикальным плющильным аппаратом.

Ключевые слова: люиерна, размерно-массовые характеристики, кормопроизводство, рентабельность, технология заготовки, косилка-плющилка.

Ф. 2. Рис. 7. Табл. 4. Лит. 20

\section{ВІДОМОСТІ ПРО АВТОРІВ}

Комаха Віталій Петрович - кандидат технічних наук, старший викладач кафедри «Агроінженерії та технічного сервісу» Вінницького національного аграрного університету (вул. Сонячна, 3, м. Вінниця, 21008, Україна, e-mail: komacha@vsau.vin.ua).

Токарчук Олексій Анатолійович - кандидат технічних наук, доцент кафедри «Технологічні процеси та обладнання переробних і харчових виробництв» Вінницького національного аграрного університету (вул. Сонячна, 3, м. Вінниця, 21008, Україна, e-mail: tokarchuk@vsau.vin.ua).

Замрій Михайло Анатолійович - студент 4 курсу спеціальності « 208 Агроінженерії», Інженернотехнологічного факультету Вінницького національного аграрного університету (вул. Сонячна, 3, м. Вінниця, 21008, Україна, e-mail: zamrij99@ gmail.com).

Комаха Виталий Петрович - кандидат технических наук, старший преподаватель кафедры «Агроинженерии и технического сервиса» Винницкого национального аграрного университета (ул. Солнечная, 3, г.. Винница, 21008, Украина, e-mail: komacha@ vsau.vin.ua).

Токарчук Алексей Анатольевич - кандидат технических наук, доцент кафедры «Технологических процессов и оборудования перерабатывающих и пищевых производств» Винницкого национального аграрного университета (ул. Солнечная, 3, г. Винница, 21008, Украина, e-mail: tokarchuk@ vsau.vin.ua).

Замрий Михаил Анатольевич - студент 4 курса специальности «208 Агроинженерия», Инженернотехнологического факультета Винницкого национального аграрного университета (ул. Солнечная, 3 , г. Винница, 21008, Украина, e-mail: zamrij99@gmail.com).

Komaha Vitalii - PhD, Senior Lecturer of the "Agroengineering and technical service " of Vinnitsa National Agrarian University (str. Sonyachna, 3, Vinnitsa, 21008, Ukraine, e-mail: komacha@vsau.vin.ua).

Tokarchuk Oleksii - PhD, Associate Professor of the Department of "Technological Processes and Equipment of Processing and Food Productions" of the Vinnytsia National Agrarian University (str. Sonyachna, 3, Vinnytsia, 21008, Ukraine, e-mail: tokarchuk@ vsau.vin.ua ).

Zamrii Mykhailo - 4th year student of specialty 208 of Agroengineering, Faculty of Engineering and Technology of Vinnytsia National Agrarian University (str. Sonyachna, 3, Vinnytsia, 21008, Ukraine, email: zamrij99@gmail.com). 